\title{
Elder Gothic And Atwood's Modernization Into New Forms
}

\author{
Saman Khalid Imtiaz \\ Department of English \\ Government College University, Lahore
}

\begin{abstract}
The article investigates how the gothic tradition of early eighteenth century has evolved into its present twentieth century form by building on its staple ingredients of awe, fear, heightened imagination, dark subterranean vaults, persecuted heroines and malevolent aristocrats. During the Romantic period the external paraphernalia of gothic devices began to be internalized, which marks the most important shift in the genre. The external markers became the internal states of the individual. The consciousness, imagination and freedom of the individual tended to be valued more than his conformation to the societal norms. The focus in the modern gothic is not on the supernatural but it operates in completely human, social and familiar world. The article reviews how Margaret Atwood, a leading Canadian author implicates gothic devices in three of her novels, Surfacing, The Edible Woman and The Lady Oracle. The most frightening gothic phenomenon which haunts Atwood's heroines is their own psyche; their gothic and heightened imagination illustrates their desires and fears in excessive forms.
\end{abstract}

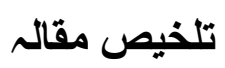

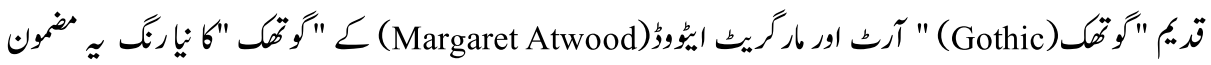

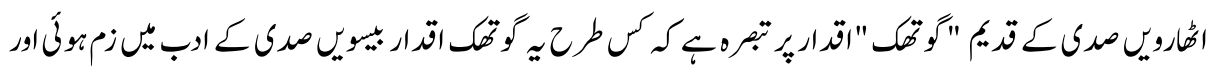

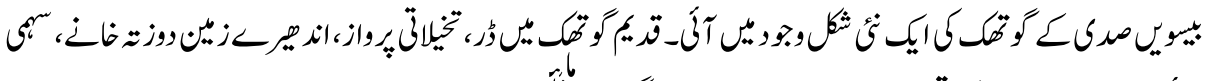

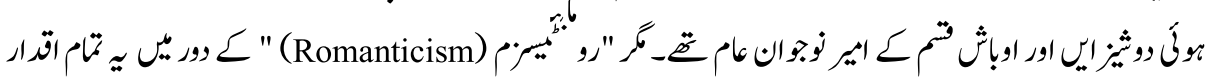

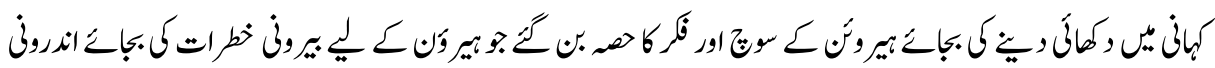

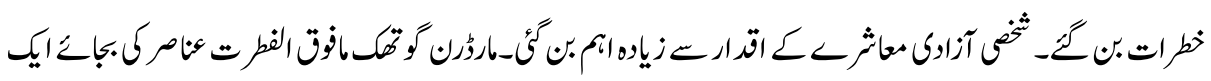

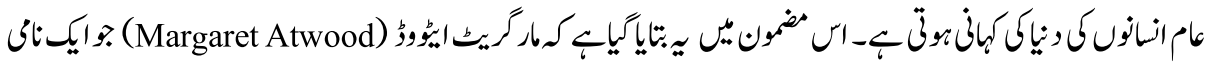

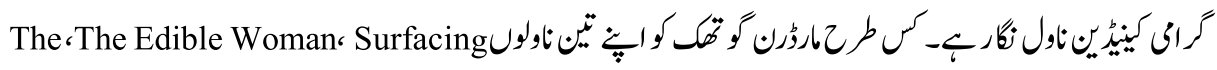

$$
\begin{aligned}
& \text { Lady Oracle }
\end{aligned}
$$

Take - an old castle, half of its ruinous,

A long gallery, with a great many doors, some secret ones, Three murdered bodies, quite fresh. 
As many skeletons, in chests and presses...

Mix them together, in the form of three volumes, to be taken at any

Of the watering places before going to bed

(Botting, 1996, P.44)

The gothic writing of eighteenth century promoted sublime awe, wonder, fear and heightened imagination. Its staple ingredients were dark subterranean vaults, gloomy forests, bandits, persecuted heroines and malevolent aristocrats. Horace Walpole's The Castle of Otranto (1764), Ann Radcliffe's Mysteries of Udolpho and M. G. Lewis's The Monk served as a blue print for this mode of writing. At that time critics condemned the gothic novels as trashy, unaesthetic and transgressive. In the eighteenth century, according to Fred Botting in his excellent analysis Gothic, the values that gave shape and direction to the aesthetics and culture of those times were Greek and Roman that attended to the classical rules. Architecture, landscapes, literature conformed to the precepts of uniformity, proportion, rationality and order. For the Victorians, the past without its civilized values had to be distinctly different from the present. "This past was called "Gothic", a general and derogatory term for the Middle Ages, which conjured up ideas of barbaric customs and practices, of superstition, ignorance, extravagant fancies and natural wildness" (Botting, 1996. P. 22). The Modernist period (in which literature paid more attention to subjective states of mind than objective analysis) was prone more to rhythm and energy than symmetry and stressed more on style and experimentation than content. In the Modernist writings, gothic was implicated in these cultural attitudes of rhythm, energy and experimentation. After the two World Wars, the individual was no more linked neatly and unproblematically to his natural and social world. French Revolution, urbanization, industrialization, disbelief in religion brought about fears and anxieties of new unknown origins. Gothic with its imaginative, wild and negative potential was an effective medium to account for such uncertainty and fears. It harbored a disturbing ambivalence. It brought together the tales of exotic adventures and superstitions from the Middle Ages; the graveyard poetry encouraged interest in nocturnal gloom and ruins and therefore an interest in afterlife; and the taste and awe for the sublime also provoked an inquiry beyond the finite and rational thinking. Therefore wonder and awe, horror and joy could be contained through gothic ambivalence. Gothic blurred any continuities from past to present and interrogated the boundaries of reason, propriety, good and evil.

In the Romantic period, the external paraphernalia of gothic writing began to be internalized removing the limits between inside and outside. This internalization according to Botting "represents the most significant shift in the genre, the gloom and darkness of sublime landscapes becoming external markers of inner mental and emotional states"(Botting, 1996. P.91-92). He also writes: "It is at the level of individual that Romantic-Gothic writing takes its bearings. The individual in question stands at the 
edges of the society...the consciousness, freedom and imagination of the subject is valued" (Botting, 1996. P.92).

The internalization of these gothic forms of fear, fragmentation and decay and the privileging of the individual are the values that are carried over to twentieth century gothic works. Tales are often narrated in first person with a psychological focus. Imagination, passion and fears soar high and confront and wrestle with the social forces. Since the individual forces are at odds with the social ones, the individual

"do[es] not have an adequate social framework to sustain a sense of identity, [he] encounters a new form of Gothic ghost, the double or shadow of himself. An uncanny figure of horror, the double presents a limit that cannot be overcome, the representation of an internal and irreparable division in the individual psyche." (Botting, 1996. P.93).

In the mid nineteenth century gothic was beginning to be subsumed within realistic fiction. The gothic machinery was no more external and tangible but existed through uncannily disrupting the fixed boundaries between reality and illusion, sincerity and corruption, past and present. These boundary disturbances are signified by mirrors, ghosts and role of doubles. The setting is no more ruins or forests but modern, industrial city. The focus is not supernatural but a completely social, human and familiar world. In the twentieth century postmodern literature, loss of identity and alienation from the self is portrayed through machinic doubles, dehumanized humans and psychotic fragmentation. The fragmentation is depicted through multiplication of realities and identities that denies any unity or wholeness. Female writers make a significant use of gothic devices to delineate female oppression within the realistic settings of twentieth century urban world. I would try to enumerate different ways through which a leading Canadian writer, Margaret Atwood has used gothic forms in her early works. Following the gothic traditions, Atwood uses the internalization of gothic fears and excessive desires as well as the focus on individual and his psycho-social environment in the urban, technologysmitten settings of her novels and poems. In her poem "Journey to the Interior", she writes:

There are no destinations

Apart from this...

Whatever I do I must

Keep my head. I know

It is far easier for me to lose my way

forever here, than in other landscapes

(Atwood, 1976. P.30) 
Therefore the most frightening gothic haunt for Atwood's heroines is their own psyche. In words of Robert Frost, they have it "so much nearer home/ To scare myself with my own desert places" (eliteskills.com). The threat does not come from the underground vaults but from their own subconscious sources. Almost all of her heroines are the prisoners of their past. The past is the sight of their prison as well as escape, pressure as well as release. Like the protagonists of Radcliffe novels, who descend into the subterranean vaults to discover a secret or escape, Atwoodian women characters descend into the murky depths of their unconscious. Their journey through such unchartered lands where there is "lack of reliable charts", where "A compass is useless" and where "words" are "as pointless as calling in a vacant wilderness" (Atwood, 1976. P.30) releases them of their psychological trauma. One such protagonist, the nameless heroine of Surfacing, living in a self-delusion is able to accept the truth about herself by confronting the demons of her past. Atwood writes in Survival; A Thematic Guide to Canadian_Literature: "Part of where you are is where you have been. If you aren't too sure where you are, or if you are sure but don't like it, there's a tendency, both in psycho-therapy and in literature, to retrace your history to see how you got there" (Atwood, Survival, 1972. P.112). (I have to mention the text here because I am mentioning more than one text written in 1972)

The nameless narrator of Surfacing comes to terms with her past through her descent into the lake. She also remembers an incident when her brother almost drowned. The narrator thinks: "If this had happened to me I would have felt there was something special about me, to be raised from the dead like that; I would have returned with secrets" (Atwood, Surfacing, 1972, P.79). Like the heroines of Anne Radcliffe novels,

"where heroines end up in ancestral halls, castles or abbeys and in those often crumbling dwellings find clues about their parents, such as how their parents died or what they bequeathed the heroines, the nameless narrator of Surfacing is literally returning to the deteriorating cottage of her childhood in an attempt to find her missing father" (Tenant, 2003. P.34)

Her father had been lost in the wilderness and had presumably drowned. Like the poets of Graveyard school of poetry, the heroine is obsessed with death, the temporal and physical world coming to an end. Her abortion made her come almost to the abyss of death: "They slipped the needle into the vein and I was falling down, it was like diving, sinking from one layer of darkness to a deeper, deepest; when I rose up through the anesthetic, pale green and then daylight, I could remember nothing... the lake was horrible, it was filled with death, it was touching me" (Atwood, Surfacing, 1972. P.152). At this point the lake acts like a graveyard for her memories (Bouson, 1993. P.37). Her diving into the lake is a literal act as well as a metaphor for descent into the subconscious (Howells, 1996. P.29) and no passage in Atwood has been more variously defined and interpreted than this gothic description of Surfacer confronting her own unconscious demons i.e. the memory 
of her aborted child and an affair with an art teacher who convinces her to have the child aborted, a lie which she couches in a story of a marriage, a still born child and a divorce. As she descends in water she sees the aborted fetus of her child coming towards her: "It was there but it wasn't a painting, it wasn't on the rock. It was below me, drifting towards me from the furthest level where there was no life, a dark oval trailing limbs. It was blurred but it had eyes, they were open, it was something I knew about, a dead thing, it was dead" (Atwood, Surfacing, 1972. P.152).

Male and female relationships and power politics form an essential part of Atwood's oeuvre. Her early texts like Surfacing and Circle Game clearly divide the male and female attributes into binary oppositions. Male space is depicted through the metaphors of mathematical squares and the female through the green landscape. In Double Persephone the male and female are opposite poles:

Love, you must choose

Between two immortalities:

One of earth, lake, trees

Feathers of a nameless bird

The other of a world of glass

Hard marble, carven wood (Atwood, 1961. P.13)

In Power Politics the male world turns gothic:

Your face is silver

And flat, scaled like a fish

The death you bring me

is curved, it is in the shape

of door knobs, moons

glass paper weights

Inside it, snow and lethal Flakes of gold fall endlessly over an ornamental scene a man and woman, hands joined and running. (Atwood, Power Politics, 1972. P.56)

The lovers are not living flesh and blood but lifeless statues and the woman has become imprisoned in thick glass as an ornamental sculpture. The phallic violence and a woman's masochism is reflected through the imagery of a "fish hook" and an "open eye":

you fit into me

like a hook into an eye

a fish hook

an open eye (Atwood, 1976. P.141) 
A perfect simile of romantic love turns into a graphic description of steady torture and the willingness with which it is accepted. The methods for silencing a woman are ages old:

What goes on in the pauses

of this conversation?

Which is about free will

and politics and the need for passion.

Just this: I think of the woman

they did not kill.

Instead they sewed her face

shut, closed her mouth

to a hole the size of a straw, and put her back on the streets, a mute symbol. (Atwood, 1976. P. 66)

Not only is the feminine oppression conveyed through gothic imagery but technology which is always a part of male space dehumanizes the modern man. Like the Surfacer's group of friends in the novel whose mouths are "lined with soiled plush... skins are red, green in squares, blue in lines...", the image of an average man is described as:

And the union leader with electrodes

clipped to the more florid

parts of his body, wired like an odd zoological diagram:

............... Reading the papers you have seen it all:

the device for tearing out fingernails,

the motors, the accessories,

what can be done with a common pin. (Davies, 1984. P.22)

The male space in Atwood is described in the gothic metaphors of square shapes, technological instruments and artificially and inorganically developed materials. In The Edible Woman, the apartment in which Peter lives is described in hybrid metaphors mingling the animate and inanimate, the effect is uncanny and grotesque.

"Inside the shiny surfaces- tiled floors, painted walls, mirrors, lightfixture- which would later give the building its expensive gloss, its beetlehard internal shell had not yet begun to secrete themselves. The rough, grey shell under skin of subflooring and unplastered wall-surface was still showing, and raw wires dangled like loose nerves from most of the sockets" (Atwood, 1998, The Edible Woman. P.57). 
Even towards the end of the novel, the building remains a strange hybrid: "Gradually the clutter of raw materials, pipes and rough boards and cement blocks, had disappeared, transmuted by an invisible process of digestion and assimilation into the shining skins that enclosed the space" (Atwood, 1998, The Edible Woman. P.23). Peter's personality is the personification of the building. Like Poe's Usher family he takes on the appearance of the place where he dwells (Tennant, 2003. P.42). He is calculating, very organized and a rational creature with an air of no-nonsense about him. The reason he is attracted to Marian in the first place is, that she seemed very sensible to him. Like his desk he is "austere and square". He smelled of cleanliness and soap all the time which Marian associates with dentist's chair and medicine.

Like The Edible Woman, the other novel which has a dark underside beneath the comic surface is Atwood's most complicated gothic novel, Lady Oracle. Joan, the protagonist herself outlines a typical gothic romance plot: "...the hero in the mask of a villain, the villain in the mask of a hero, the flights, the looming death, the sense of being imprisoned..." (Atwood, 1998, Lady Oracle, P.286) and after that a happy ending. Joan longed for the simplicity and assuredness of the gothic world, "where happiness was possible and wounds were only ritual ones. Why had I been closed out from that impossible white paradise, where love was as final as death, and banished to this other place [the real world] where everything changed and shifted?' (Atwood, 1998, Lady Oracle, P.286).

Therefore the gothic world is a fixed world where the people are either angels or demons. Through flashbacks we come to know about Joan's overweight and unhappy childhood; she has an extremely domineering mother who is always trying hard to make Joan lose weight but to no avail and a father who is disinterested in either Joan or her mother. At the center of female gothic tradition is the fear of male violence or male rejection (Fee, 1993. P.63). Joan's mother is a rejected wife and she instills this fear in her daughter. For her men and women were not complex creatures but two-dimensional. She tells Joan that good men did things for you and bad men did things to you. Margery Fee tells us that many feminist critics have argued that gothic novels appeal to women because they at first echo the fears their readers have of violence or indifference from men and then allay them by showing how the violence or indifference originates in love and has been misinterpreted by the overfearful woman (Fee, 1993. P.61).

\section{Janice Roadway Maintains}

"In suggesting that the cruelty and indifference that the hero exhibits toward the heroine in the early part of the novel are really of no consequence because they actually originated in love and affection, the romance effectively asserts that there are other signs 
for these two emotions than the traditional ones of physical caresses, oral professions of commitment, and thoughtful care" (Fee, 1993. P.62).

Like the female readers of gothic romances who try to discover the truth about men by observing the behaviors of men around them and try to fit them into prefigured categories, Joan despite Arthur's nonchalance, thinks that since in the gothic romance heroes are supposed to be aloof, Arthur's attitude is a normal one. She even comes to believe that his indifference is "feigned" and "at any moment now his hidden depths would heave to the surface; he would be passionate and confess his longstanding devotion. I would then confess mine, and we would be happy" (Atwood, The Lady Oracle, 1998. P.197). The Harlequin romance instead of providing positive ways of dealing with male violence or rejection tries to mask the complexities of human relationships, giving the readers, the reassurance that their fears are not real and they need not worry because one day, some day in the distant future a prince charming will come and all their problems would be resolved. Joan is waiting for such a miracle to happen. Instead of taking her fate in her own hands and getting out of the victim mentality, she sees herself as persecuted and as helpless as a gothic heroine. Unlike a responsible writer, instead of providing alternative roles to her women readers, she rationalizes her own act of "perpetuat[ing] degrading stereotypes of women":

"Life had been hard on them and they had not fought back, they'd collapsed like soufflés in high wind. Escape wasn't a luxury for them, it was a necessity... and when they were too tired to invent escapes of their own, mine were available for them at the corner drugstore, neatly packaged like other painkillers (Atwood, Lady Oracle, 1998. P.30-31).

Like the Surfacer and Marian in The Edible Woman, Joan also is an escape artist. It is sad that an imaginative artist like Joan does not use her reason and intelligence in a matured way and is addicted to her "painkillers": "All my life I had been hooked on plots", she tells us.

Another terror at the heart of gothic novel is a woman's loss of identity (Fee, 65). Joan herself is not sure about which identity to assume. Her deliberately cultivated double identity also provides her with a form of escape. On her birth her mother named her after Joan Crawford whose real name was Lucille LeSueur. Her pen name is Louisa K. Delacourt, the name of her dead aunt and 'Lady Oracle' is the name for which she is only a medium (since it is produced by automatic writing). It is not the freedom of writing that she enjoys but the freedom of being two different people at the same time and not having to be responsible for the acts of the other:

"The real important thing was not the books themselves which continued to be much the same. It was the fact that I was two people at once, with 
two sets of identification papers, two bank accounts, two different groups of people who believed that I existed. I was Joan Foster... but I was also Louisa K. Delacourt.

As long as I could spend a certain amount of time each week as Louisa, I was all right" (Atwood, Lady Oracle, 1998. P.213).

This loss or duality of identity is reflected through mirroring, doubling or reduplicating techniques which is a familiar gothic form since the days of Jekyll and Hyde. Joan herself feels that media is duplicating her distorted image:

"it was as if someone with my name were out there in the real world, impersonating me, saying things I'd never said but which appeared in the newspaper, doing things for which I had to take the consequences: my dark twin, my fun-house mirror reflection ... She wanted to kill me and take my place" (Atwood, Lady Oracle, 1998. P.213).

Since Joan's sense of self is highly insecure, she starts having hallucinations in the mirror that her old fat outline of the body is appearing with her present image in the mirror. Joan does not have an adequate social framework to sustain a sense of identity and thus encounters a new form of Gothic ghost, the double or shadow of herself. She becomes an uncanny figure of horror, her double image symbolizing an internal and irreparable division in her psyche.

This mirror image is a split off from her own psyche of the self that is so angry at her mother that she cannot admit it to her conscious self. This is the self that makes her see her mother as a "triple headed monster". So Joan's monstrous, unreasonable and dark self is projected onto her mother. Almost everyone in the novel has a dark, shadowy side of character. Joan's mother "puts on her face" with her lipsticked mouth, "her real one showing through the shadow" (Atwood, Lady Oracle, 1998. P.68). Her father, almost like the daffodil man who might be the flasher in the ravine, is a duplicitous personality. Aunt Lou, although benevolent and harmless, is having an affair with a married man. This is the multiple personality that Joan depicts through her poem 'Lady Oracle':

She is one and three

The dark lady the redgold lady

the blank lady oracle

of blood, she who must be

obeyed forever (Atwood, Lady Oracle, 1998. P.226).

The poem hints at the repressed memories of her mother. During the automatic writing sessions she feels a dark figure standing beside her in the mirror, a figure who she consciously thinks "has nothing to do with [her]" but ultimately recognizes as her mother. 
"It had been she standing behind me in the mirror ... My mother was a vortex, a dark vacuum, I would never be able to make her happy. Or anyone else. May be it was time for me to stop trying" (Atwood, Lady Oracle, 1998. P.329). This realization comes at the same time when her gothic plots start going wrong. The set gothic formula of her last gothic novel 'Stalked By Love' had somehow twisted and takes an unexpected turn. In place of sending her heroine into the maze she sends the villainess, Felicia. In one of her interviews Atwood says: "In Gothic tales the maze is just the scare device. You have an old mansion with winding passages and a monster at the center. But the maze I use is a descent into the underworld" (Ingersoll, 1992. P.47). Simultaneously as Joan is in the process of scrutinizing her unconscious self and allows the repressed love for the mother to surface, there is a crucial change in her gothic plot. Joan instead of identifying with her heroine starts showing sympathy for Felicia. Real life characters start merging with the gothic plot characters. Redmond, the gothic hero becomes Arthur reaching for Felicia who becomes Joan. The hero alternately becomes all the men with whom Joan has been involved in her life and ultimately becomes a figure of death. So contrary to the happy ending, the plot becomes as complex, ambiguous and unexpected as in real life. Joan now realizing the perils of gothic thinking, plans to give it up and start writing science fiction. She perceives that she has been casting real people in these two dimensional roles and 'killing off' anyone who does not suit her including herself. Will she be a successful woman after getting rid of this bi-polar thinking? If not she will at least be a happier one.

\section{References}

Botting, Fred. Gothic; New Critical Idiom (Routledge, London and New York, 1996)

Atwood, Margaret. Selected Poems 1965-1975 (Houghton Mifflin Company, Boston, 1976)

http://www.eliteskills.com/c/13216

Atwood, Margaret. Survival; A Thematic Guide to Canadian Literature (Toronto, Anansi, 1972)

Tennant, Colette. Reading the Gothic in Margaret Atwood's Novels (The Edwin Mellen Press, 2003)

Bouson, Brooks. J. Brutal Choreographies ( The University of Massachusetts Press, Amherst, 1993)

Howells, Coral Ann. Modern Novelists: Margaret Atwood (St. Martin's Press, New York, 1996) 
Atwood, Margaret. Double Persephone (Toronto: Hawkshed Press, 1961)

Atwood, Margaret. Power Politics (Toronto: House of Anansi, 1972)

Atwood, Margaret. "The Arrest of the Stockbroker", qtd in Feminist Poetics by Frank Davey (Talon Books, Vancouver, 1984)

Atwood, Margaret. The Edible Woman (The First Anchor Books Edition, 1998)

Atwood, Margaret. Lady Oracle (The First Anchor Book Edition, 1998)

Fee, Margery. The Fat Lady Dances; Margaret Atwood's Lady Oracle (ECW Press, 1993)

Ingersoll, Earl. Margaret Atwood: Conversations (London: Virago 1992)

Atwood, Margaret. Surfacing (Markham: Paperjacks Ltd, 1972)

Saman Khalid Imtiaz is Assistant Professor in the Department of English, Government College University, Lahore. 